\title{
INDUSTRY WATCH
}

\section{Mongoven, Biscoe \& Duchin: destroying tobacco control activism from the inside}

\section{Stacy M Carter}

Tobacco Control 2002;11:112-118

Mongoven, Biscoe \& Duchin, a specialist firm based in Washington DC, has honed a niche as expert intelligence gatherers, helping tobacco companies such as Philip Morris and RJ Reynolds to damage tobacco control efforts, including the WHO's Framework Convention on Tobacco Control.

M ongoven, Biscoe $\&$ Duchin (MBD) is a specialist PR firm based in Washington DC, run by professionals who have made a career of undermining consumer rights and social justice. MBD are less well-known than companies such as Hill \& Knowlton, BursonMarsteller, or Edelman PR Worldwide. They tend not to engage in public communications under their own banner, and don't have a website, deliberately maintaining a low profile. PR-managed anti-activism is a global industry, ${ }^{1}$ but MBD are special, having honed a niche as expert intelligence-gatherers, helping multinationals to bring down advocacy campaigns both through advice and through practical, logistical support. Tobacco control activists, NGOs and even bureaucrats need to be alerted to the possibility of MBD infiltration of their activities and of their own ranks, particularly given internal tobacco industry documents demonstrating that MBD has been used by both Philip Morris (PM) and RJ Reynolds to gather intelligence and provide strategic advice to damage tobacco control efforts, including the current Framework Convention on Tobacco Control (FCTC) process.

\section{IGNOMINIOUS BEGINNINGS}

John Stauber and Sheldon Rampton from the Centre for Media and Democracy have been the conduit for most of what we know about MBD, and the following background information is drawn largely from their books, Trust us, we're experts and Toxic sludge is good for you, ${ }^{12}$ in which they piece together the story of the creation and operation of the world's leading NGO-busters. It starts with a boycott coordinated by INFACT in the late 1970s and 1980s in response to Nestlé's active promotion of infant formula in developing countries, a practice which led to widespread infant death due primarily to lack of access to clean water. After three years of confrontation, Nestlé changed tack and hired Jack Mongoven, an ex-journalist who had served as director of press relations for the Republican National Committee and an advisor to the Nixon, Ford and Reagan presidencies. He and Rafael Pagan devised a "divide and conquer" plan to bring down the boycott not by answering NGO's concerns, but via smoke and mirrors. They formed the Nestlé Coordination Centre for Nutrition (NCCN: Rafael Pagan, president; Jack Mongoven, vice president) and implemented a strategy that would provide the blueprint for Mongoven's future career. NCCN successfully recruited organisations to the proNestlé camp, dividing the boycott's support base, then established the "Nestlé Infant Formula Audit Commission" (NIFAC), an "independent" group, including former boycotters, to "monitor" Nestlé's compliance. It was an ingenious strategy, the boycott was thwarted, and Pagan and Mongoven's reputations were made. No longer needed at Nestlé, they formed 'Pagan International' and worked for the defence, chemical, pharmaceutical, and food industries until a scandal scuttled the company and Jack Mongoven left to form MBD with Alvin Biscoe and Ron Duchin.

\section{STRATEGIC ATTACK}

Ron Duchin graduated from the US Army War College, and served as special assistant to the Secretary of Defence and director of public affairs for the Veterans of Foreign Wars (VFW) before joining Pagan International and then MBD. In 1991 he gave a speech to the US National Cattlemen's Association describing how MBD works to divide and conquer activist movements. Duchin explained that activists fall into four categories: radicals, opportunists, idealists and realists, and that a three-step strategy was needed to bring them down. First, you isolate the radicals: those who want to change the system and promote social justice. Second, you carefully 'cultivate' the idealists: those who are altruistic, don't stand to gain from their activism, and are not as extreme in their methods and objectives as the radicals. You do this by gently persuading them that their advocacy has negative consequences for some groups, thus transforming them into realists. Finally, you co-opt the realists (the pragmatic incrementalists willing to work within the system) into compromise. "The realists should always receive the highest priority in any strategy dealing with a public policy issue ... If your industry can successfully bring about these relationships, the credibility of the radicals will be lost and opportunists can be counted on to share in the final policy solution."1 Opportunists, those who are motivated by power, success, or a sense of their own celebrity, will be satisfied merely by a sense of partial victory.

"The realists should always receive the highest priority in any strategy dealing with a public policy issue ..." 
MBD specialises in providing this strategy to its clients in a customised form based on "public policy intelligence" specific to their concerns. Corporations pay a large monthly retainer for the privilege: RJ Reynolds, for example, paid MBD a retainer of US $\$ 14,000(£ 10,000$, Euros 16,078$)$ per month in November and December of $1994 .^{3}$ MBD maintain extensive files on organisations and their leaders including personal biographies, funding sources and susceptibility to co-optation. They also produce special reports, which they sell to their corporate clients for sums upward of US\$1000 ( $£ 714$, Euros 1148). They get their information by joining mailing lists, reading newsletters and other publications, and using spies (people generally claiming to be concerned citizens or freelance journalists) to gather inside information at advocacy events and from within advocacy organisations, sometimes infiltrating the organisation and gathering information over long periods.

MBD also uses mail and telephone "surveys" of activist organisations, generally framing their true objectives euphemistically. In 1995, The Wilderness Society, an Australian environmentalist group, received a letter from MBD. Attached information described MBD as a firm "committed to the concept that corporate decision makers must develop a better appreciation of the public interest movement", and described MBD's role as "assist[ing] clients in developing long-term strategies to resolve contentious public policy issues in a balanced and socially responsible matter." The letter demonstrates the international nature of MBD's efforts, stating that "increasingly, our clients have been seeking information and guidance concerning developments in Asia. To that end, MBD has set out to develop a series of 'profiles' of some of the leading non-governmental entities in Asia. We received exceptional levels of cooperation from NGOs in Europe and Latin America for previous projects, and we hope that the Asian community will be equally helpful ..." ${ }^{4}$ A long list of specific questions was attached, including "who are your principal officers and staff?"; "what is your annual budget and what are your sources of funding (foundation grants, membership donations, etc.)?"; and "what are your most recent campaigns and achievements?" The Wilderness Society was aware of MBD because of the Centre for Media and Democracy's work, and forwarded the material to PR Watch. ${ }^{5}$ Despite the misleading descriptions of MBD's function in their surveys, and the assumed identities of MBD spies, MBD's representatives always claim to be "outraged" at suggestions that their information gathering amounts to espionage. ${ }^{12}$

\section{"MBD also uses mail and telephone "surveys" of activist organisations, generally framing their true objectives euphemistically"}

\section{MBD AND TOBACCO CONTROL}

Pagan and Mongoven had loose business links with the tobacco industry as far back as the 1980s, representing NCCN on the League of United Latin American Citizens Business Council along with Peter G Sparber, Vice President of the Tobacco Institute. ${ }^{6}$ By the 1990s, MBD was working directly for the industry. A 1993 list of corporate affairs expenses for Philip Morris Companies Inc includes US\$85,500 (£60,714, Euros $97,618)$ for the services of Jack Mongoven. The justification of the expense demonstrates the synergistic role Mongoven has played within the Philip Morris group of companies:

"Mongoven has a very unique niche. At our request, he will do investigatory work on various activist groups and flag problems, i.e. EDF [Environmental Defence], animal rights groups, etc. KGF [Kraft General Foods] uses the majority of his services. This contract ought to be split between KGF and WRO [Washington Regulatory Office]."

Robert Blumel and Ronald Duchin consult primarily for RJR. The earliest reference to Duchin is in 1986, noting that he was an ally who presented pro-industry arguments at military commissaries under the cloak of apparent independence. ${ }^{8}$ Duchin works occasionally for $\mathrm{PM}^{9}$ and there is also occasional coordination of MBD activity between RJR and PM. $^{10}$

MBD's efforts for the tobacco industry can be divided into five main areas of focus:

(1) environmental health issues;

(2) monitoring or co-opting NGOs;

(3) working against the FDA;

(4) enabling character assassination of tobacco control figures; and

(5) undermining the globalisation of tobacco control, including the Framework Convention on Tobacco Control.

\section{INDOOR AIR, ETS AND GENETICALLY MODIFIED ORGANISMS (GMOS)}

MBD is particularly experienced in fighting environmental NGOs, with its areas of interest including endangered species, rainforest, hazardous and toxic wastes, environmental justice, drinking water, pesticides, and oil spills, just to name a few. ${ }^{2}$ There is evidence from the documents that MBD has provided general expertise to the tobacco industry on environmental activism, ${ }^{11-13}$ including to "The Working Group", a crossindustry body which included General Electric, RJR Nabisco, Pfizer Inc and Dow Chemicals. ${ }^{14}$ In the late 1990s, MBD intelligence was important to Philip Morris' planning to ensure that they were able to continue to use genetically modified organisms across the PM group of companies. ${ }^{15-19}$ But it was in the early to mid 1990s that MBD did most of their environmental work for the industry, on the issue of indoor air quality (IAQ). Mongoven delivered several papers to PM on aspects of IAQ. ${ }^{20-23}$ They detail the relevant agencies and processes, forecast likely legislative actions, and analyse risk management implications and potential impacts on a range of associated concerns. They also highlight his trademark framing of the public as confused and woolly-headed, his lack of sympathy for the plight of consumers, and his tendency towards a dramatic communication style. In 1991 he advised that indoor air quality was "one of the issues we see beginning to receive more attention from the activists... Much of this issue has been based on an amorphous fear of the unknown, but that will not prevent it from becoming a real factor which will have to be dealt with." ${ }^{\prime 2}$ In the same year he advised PM that people professing to have multiple chemical sensitivity "think of themselves as being like the canaries that miners took below ground to provide a warning in case of dangerous levels of gas in the air. Unlike the canaries, however, these people will not just die quietly."21

In 1992, Mongoven gave PM the inside word on the Environmental Protection Agency, advising with regard to IAQ: "we believe it to be in the interests of our clients to prefer Occupational Safety \& Health Administration (OSHA) regulation to EPA ..."24 Two years later, Ron Duchin and Robert Blumel were fighting OSHA for RJR. In a 1994 report setting out status and costings for their work and requesting a budget of US $\$ 41,500(£ 29,625$, Euros 47,660$)$, they reported on their achievements in the area of indoor air quality, highlighting an "indoor air quality project" which had succeeded in "recruit[ing] veterans organisations in a campaign against onerous regulations and legislation, particularly OSHA's proposed Indoor Air Quality regulation.." ${ }^{3}$ MBD facilitated veterans' groups testifying before OSHA, addressed veteran's organisations, and set up a "survey centre" which gathered and dispatched information via an ever expanding mailing list, in keeping with the regular MBD strategy of creating a purpose-built third party to advocate for their client's views ("third party strategy" in PR parlance). The survey collected information on veteran's opinions and estimates of 
compliance in veteran's clubs, which was used in testimony and was posted out to veteran's organisations. But its primary purpose was "bring[ing] the indoor air quality issues to the attention of veterans organisations' leadership without appearing to be promoting a specific industry's interest". MBD noted that the project was "a powerful force for recruiting not only veterans organisations and individuals within those organisations, but it can be expanded to other constituencies..."

\section{MONITORING AND CO-OPTING NGOs}

MBD have applied their specialty, monitoring and/or co-opting NGOs, to a number of tasks for the industry. In 1994 Duchin and Blumel undertook "a crash effort to recruit and retain national and state organisations, as well as individuals, to a broad based ad hoc coalition to Get Government Off Our Back." ${ }^{\prime 3}$ Mongoven provided PM with a fairly pedestrian analysis of the 1998 meeting of Society for Research on Nicotine and Tobacco's Annual Meeting, ${ }^{25}$ and in 1999 he investigated the possibility of PM obtaining liaison status at the International Standards Organisation, ${ }^{26}$ reinforcing existing evidence of industry's interest in influencing the ISO. ${ }^{27}$ More colourful is MBD's engagement with INFACT, a corporate watchdog organisation that went head to head with Mongoven during the Nestlé boycott in the 1970s and 1980s. MBD have advised both RJR and PM regarding INFACT, in ways which differed substantially in tone. In 1995 Duchin was suggesting that the joint participation of INFACT and the Interfaith Centre on Corporate Responsibilities (ICCR) in the FDA tobacco regulation issue was a significant threat that he could manage for RJR: "the involvement of both INFACT and ICCR in any activist campaign brings a unique dimension to the issue-the power of perceived church sponsorship of the activist groups. MBD has been following the two organisations and their leaders for many years. We know their styles of leadership and their philosophies they adhere to. We can be of help to RJR in monitoring and developing strategies relative to these groups and their activities." 28

Less than three years later, Mongoven was slamming his old enemies to PM. His detailed report on INFACT's Hall of Shame provides details such as planned targeting of board members, the text of letters to be sent to them, and the predicted course of the campaign. Overall though, Mongoven appears to be aiming to paint INFACT as being rudderless and grasping at causes for the sake of engaging in activism, while being careful to cover his risk-management bases. "Despite INFACT's grandiose plans and threats, we do not believe that the organisation represents the threat that it once did ... It is important to note, however, that demonstrations at corporate annual meetings are often disruptive and embarrassing to corporate management." ${ }^{29}$ These contrasting framings of INFACT raise some questions, impossible to answer from the documents, about the extent to which MBD play their clients as hard as their opponents. Mongoven and his colleagues have worked to gut causes such as the prevention of infant death in developing countries and the fight against apartheid: high moral principles are notably absent. MBD's advice on IAQ and on INFACT may have differed because of changed circumstances. Alternatively perhaps even corporations should be wary of professionals who specialise in spin.

\section{WORKING AGAINST THE US FOOD AND DRUG ADMINISTRATION (FDA)}

RJR commissioned MBD to actively work against the FDA's attempts to regulate tobacco in 1994-95. As always with Ron Duchin, it seems, the strategy included co-optation of veteran's groups and the use of third party strategy ("develop an entity"):
"MBD has now undertaken to assist RJR with its FDA project to obtain one million plus signatures in opposition to the FDA's potential regulation of tobacco products. MBD will develop an entity and message to provide petitions to local posts and grassroots veterans organisation... additional signatures can be obtained from members of social and fraternal organisations which work closely with veterans posts." ${ }^{\prime 3}$

A fax from the senior director of RJR's Public Issues Department gives the most detail about the advice Robert Blumel was giving on the FDA process, and suggests some incredulity:

"Faxed proposed rule to Bob Blumel on Thursday and followed up with him today. Blumel feels $(\$ \$ \$)$ that getting Congress to take an interest in the issue will be easier as it can be argued that the cost of the regulations will add to the deficit. He suggests a cost benefit analysis or study from one of the think tanks here in town (CEI, Heritage, CATO) to demonstrate that not only will the proposal not have any effect on children smoking, but that it will cost the taxpayers a whole lot of money. He thinks attacking the proposal from a cost arguments could be the necessary hook to pull in conservative deficit hawks on the hill. In addition, Blumel is going to the FDA on Monday to poke around and see some of his contacts to see if he can get a feel for what they think of Kessler's proposed regs. I'll be having lunch with Blumel on Monday afternoon." ${ }^{\prime 30}$

Blumel certainly appears to have been gathering information from inside both Congress and the FDA on the proposed regulatory changes. The meaning of the aside " $(\$ \$)$ " is unclear, but it is possible that Hyde was referring to the cost of Blumel "feeling" anything on behalf of RJR. MBD certainly didn't have an open chequebook to pursue the FDA process, as evidenced by Duchin's suggestions four months later that for a fee he could investigate the NGOs' lobbying of the FDA. ${ }^{28}$

\section{CHARACTER ASSASSINATION RESEARCH}

A particularly nasty specialty of MBD is preparing backgrounders on individuals who lead tobacco control efforts, presumably to enable the industry to discredit them in the eyes of the public or decision makers. PM specifically requested that MBD investigate Dr Sydney Wolfe of the Health Research Group (HRG), Cliff Douglas of the American Lung Association, and Scott Ballin of the American Heart Association in 1992. MBD sent information they already had on file and advised "If we had a day or so we could expand on this information significantly." ${ }^{\prime 31}$ As well as general career path and network information, Mongoven's somewhat desperate attempts to identify a character flaw involve an association with prominent consumer advocate Ralph Nader and a very tenuous suggestion that this may have influenced the awarding of a grant. ${ }^{31}$ Far more vicious is MBD's work on Dr Gro Harlem Brundtland in relation to her appointment as Director General of the WHO. Brundtland moved tobacco control to the top of the WHO priority list on her appointment, thus posed a significant threat to the industry. In 1998 Mongoven provided intelligence both on the appointment process and Brundtland's loyalties, predicting that she was certain to be elected to the position. ${ }^{32}$ Six months later, Jack Mongoven provided a memo bluntly entitled "Brundtland and Whales", which highlights the fact that Norway engaged in whaling during the period that Brundtland was Prime Minister, in opposition to the 1986 moratorium declared by the International Whaling Commission (IWC). ${ }^{33} \mathrm{~A}$ folder of materials found in Matt Winokur's office labelled "WHO Planning" contained the Greenpeace publications which were attached to this memo. ${ }^{34}$ Criticism of continuing whaling is readily justified, but from the mouth of Jack Mongoven, committed opponent of animal rights and environmental concerns, it is highly ironic. 


\section{WORKING AGAINST THE GLOBALISATION OF TOBACCO CONTROL}

The final area in which MBD has worked for the industry is in undermining WHO processes, particularly the Framework Convention on Tobacco Control (FCTC). The FCTC was initiated in 1996 by the World Health Assembly (WHA), an association of 161 governments under the auspices of the WHO. It is due to be delivered by May 2003 and will provide legally binding guidelines for international governance on tobacco control. Any convention is generally associated with a set of protocols. These are detailed legal instruments on particular sub-issues (in the case of tobacco, issues such as advertising or taxation), which can be written consecutively with or following the completion of the convention itself. An ongoing tension exists in any convention process because protocols are individually ratified, separate from the convention itself. Thus a framework convention negotiation can pursue one of two paths: a weak convention which most countries will ratify plus strong protocols which may be delayed indefinitely and to which few will sign; versus a strong convention, which may be ratified by fewer countries but will provide an international standard for comprehensive global governance. The FCTC and its protocols must be accepted by the WHA before being ratified, and every member-state of the WHA has one vote. Thus every nation-state in the WHA has at least a nominally equal say in the final "yes or no" decision, although the political and fiscal reality is far more complex.

The FCTC development process started with two working groups in 2000, which set out an initial framework. It is now continuing in a series of sessions of the Intergovernmental Negotiation Body (INBs). There have been three INBs - a fourth is planned for March 2002. The secretariat for all of the formal meetings of the FCTC is the Tobacco Free Initiative (TFI), a WHO cabinet project created by Gro Harlem Brundtland at her appointment in 1998 to focus international attention, resources and action on global tobacco control. NGOs formally recognised by the WHO can observe and make formal "statements" at FCTC meetings: NGO meetings are thus scheduled to precede and coincide with FCTC meetings. Opportunities for lobbying occur at the INBs, and also at Regional Intersessional Meetings. These meetings occur within the six WHO "regions" (Africa, the Americas, Eastern Mediterranean, Europe, South-East Asia and Western Pacific) as well as within other groupings (for example, ASEAN). They are not part of the formal process, occurring at the region's discretion, but groups of nations can and increasingly do speak formally at meetings of the INB.

In July 2000, a WHO "Committee of Experts" released a report entitled Tobacco company strategies to undermine tobacco control activities at the World Health Organisation..$^{35}$ In it was detailed evidence of a wide range of deliberate ploys by big tobacco to "contain, neutralise and re-orient" WHO tobacco control activities. Based on what they had found, the committee concluded "it is likely that tobacco companies will attempt to defeat the proposed Framework Convention on Tobacco Control, or to transform the proposal into a vehicle for weakening national tobacco control initiatives. Such a campaign is likely to be sophisticated and sustained, and to use tactics similar to those described in this report." ${ }^{\prime 35}$

The expert committee was absolutely right. From 1997, MBD has been working against the FCTC process for PM, and advising PM on undermining the WHO in general (in addition to the energies directed against the Director General personally). In August of 1998 Mongoven analysed the framework convention process, including "strategic recommendations and case studies of past and on-going negotiations.",36 37 Mongoven starts by ensuring that his client is convinced of the seriousness of the situation. "Once a framework convention reaches this stage a final product is virtually inevitable", he counsels, and tobacco executives should learn from the
Framework Convention on Climate Change, in which industry did not participate early because they made the mistake of assuming that the US would not be a signatory. When they realised that their predictions were misplaced, they were forced to "fight a decidedly uphill battle against activists." ${ }^{37}$

"Activists are aware that the existence of a framework convention allows them to gradually escalate the severity of restrictions through adoption of additional protocols never envisioned at the time of treaty ratification ... In conventions where industry has participated from an early stage it has played an important role in shaping the framework convention and thus the protocols. The pharmaceutical industry's involvement in the Framework Convention on Biodiversity is a good example of Western industry participating in the development of what could have been a very onerous agreement but which has become an acceptable regulatory regime.".37

Action is thus required to influence both the treaty and the protocols, Mongoven advises: ${ }^{37}$

"The first alternative to an onerous convention is to delay its crafting and adoption. Since the US Congress only enters this issue when the treaty must be ratified, the current administration will be responsible for US input and negotiations of the treaty. Any pressures to delay the finalisation of the convention would require the combined efforts of several individual or coalitions of countries and various NGOs..." ${ }^{37}$

Mongoven advises that the working groups are the key site of influence for NGOs, and that "the key intervention points to delay or strongly influence movements in negotiations are the biennial meetings of the WHA [World Health Assembly] where all the individual nation-states participate ... The first target WHA would be 1999. Any strategy to deal with same would have to be in place by mid-1998." ${ }^{37}$

"Aside from delaying the adoption of a convention the company is best served by participating in the development of the agreement. It would be in the company's interest to have the treaty focus entirely on protecting children and leaving adult choice protected ..."

"Any effort to influence the convention finally adopted will require a highly sophisticated and well coordinated central strategy ... the corporation must have a cohesive and consistent strategy and focal point or it will be working against itself in an international tribunal . . Compromises can be significantly influenced, but to do so requires a clear cut decision to do so, agreement on specific objectives to be sought, a comprehensive strategy to achieve those objectives and a central structure to implement the strategy worldwide." ${ }^{37}$

Mongoven worked hard for PM in the last months of 1998, but many of the reports he wrote have not been included in PM's online document collection. From covering memos we know that he completed an analysis of the creation and roles of NGOs in relation to UN processes, ${ }^{38} 39$ a briefing paper on "the background and current thinking at WHO on tobacco control", ${ }^{40}$ which was to be used for lobbying purposes, ${ }^{41}$ and a paper analysing International Framework Convention issues. ${ }^{42}$ The memo covering the WHO paper suggests that Mongoven is making the most of UN contacts: "As you can read from our memo on the interview with Mr Uranga, ${ }^{43} 35$ WHO is stepping on a lot of toes - perhaps something we ought to watch more closely." ${ }^{40}$

Not long afterwards, MBD were asked by PM's Matt Winokur, director of corporate affairs for PM International in Washington, to "look into" another WHO-sponsored event, an International Policy Conference on Children and Tobacco, held in Washington DC on 18 March $1999 .{ }^{44} 45$ The conference aimed to devise healthy public policy, and was a relatively closed and expert affair rather than a general informationsharing opportunity. ${ }^{46}$ In MBD's analysis of the media 
announcement of the conference, ${ }^{47}$ Mongoven also delivers the inside word on the international framework convention, noting that he had had a private conversation with TFI staff about their plans to enlist the support of US politicians for the FCTC, and that TFI were "very encouraged by the receptivity of American policymakers to advancing the IFC". ${ }^{47}$

By April, Mongoven had moved on from general background papers to specific analyses of components of the FCTC, was starting to focus on the NGOs involved in the process, and was reporting monthly on his ongoing investigations. He reported that an NGO meeting was scheduled at WHO on 15 and 16 May to coincide with the WHA in Geneva, organised by the International Non Governmental Coalition Against Tobacco (INGCAT), at that time run by Karen Slama. "The purpose of the meeting is to mobilise important international organisations which have not taken a stand against tobacco ... Slama has scheduled a press conference for May 14 which we will cover." ${ }^{\prime 4}$

That day Mongoven also forwarded an intelligence report on activities of the Tobacco Free Initiative. ${ }^{49}$ The report lists the TFI activities in progress and the personnel involved, and details methods for selecting tobacco control activists for awards on World No Tobacco Day 1999, identifying one of the planned recipients. The TFI's activities are detailed:

"The review of the Children's Rights Convention with reference to tobacco is almost completed. The lawyer handling it is finishing his TFI contract next month, and will move on to work with UN High Commission of Refugees ... The UNICEF Adolescent smoking survey in nine countries is about to begin and continue for two months. Apparently, some problems still have to be resolved but the launch is being planned. The survey will be handled by education authorities and tobaccocontrol NGOs in the participating countries ... GlobaLink and TFI are developing a joint web-site with help from IUAC ... Framework convention is still in its political support-seeking stage. WHA is expected to either give it impetus or downgrade it at its upcoming meeting. It appears there is some reserve on the part of some representatives to make it as high a priority as the Director General has. Drafters of the IFC are making slow headway and have yet to come up with a concrete outline they can agree on." ${ }^{\prime 9}$

By June 1999, as the document evidence begins to thin out, there is proof that PM was following through on MBD's advice. The last two documents, from mid-1999, suggest that PM was engaging with the 1999 WHA, as suggested by Mongoven in 1997, and that they may be approaching the FCTC problem in terms of regions. Winokur emailed Anne Kush and others on 6 June regarding "draft cover for followup to regions," advising "I'll get Mongoven's transcripts sent up by disc so we can send those out as well," ${ }^{50}$ and on 18 June he distributed "revised country comments at WHA compiled by MBD". ${ }^{51}$ The available documents finish at that point, but the FCTC process continues, and so does MBD's involvement. On 15 March 2000 in Washington DC, the US Centers for Disease Control and Prevention held public hearings to solicit "comments from the public" on the FCTC. Attending, but not presenting, was a Mr Matthew Vanek, listed as a "Policy Analyst", from MBD. ${ }^{52}$ The fourth round of negotiations of the FCTC will be held in Geneva from 18-23 March 2002, and it seems highly likely that MBD are continuing to monitor developments and advise PM as to how to undermine the process from within.

\section{CONCLUSION}

The most worrying of all of MBD's efforts is their current engagement with the FCTC process. There is no reason to think that MBD have stopped working for PM on the issue, and it is probable that PM has a centralised coordinated strategy to undermine the FCTC as recommended. The question is one of method - how they are approaching the problem. There are several clues from the documents:

(1) an intention to delay the FCTC

(2) an intention to focus the convention on children, framing the issue as one of "adult choice"

(3) an interest in what content is included in the convention and what is left to be dealt with in the protocols

(4) a recommendation that the "combined efforts of several individual or coalitions of countries and various NGOs' would be required

(5) a focus on the meetings of the World Health Assembly as key intervention points, suggesting an intention to co-opt the votes of individual nation-states through lobbying

(6) an interest in approaching the issue by region.

Certainly since the inauguration of President George W Bush in 2001, one of the individual nations exerting influence favourable to the industry has been the USA. ${ }^{53}$ This is unsurprising in light of Mongoven's watertight Republican links and the US's status as a tobacco exporter. The USA are not the only country putting forward positions favourable to the industry: tobacco industry operatives have in fact attended FCTC negotiations as "representatives" of countries with nationalised or influential tobacco industries. ${ }^{54}$ WHO's system of "regions" is also a potential weakness, because each contains at least one country which is weak on tobacco control and likely to support the interests of the industry, and it may be this potential portal which MBD were exploiting in their "followup to regions". The question of the strength of the convention, including the choice of matters to be left for the protocols, is likely to be a central consideration of INB4, and there is enormous potential for the industry, via operatives like Mongoven, to "divide and conquer" the process and its participants on this issue.

Two major questions arise regarding the potential influence of Philip Morris on the FCTC via Jack Mongoven. Firstly, how the FCTC is progressing. Although the WHO is making official papers available, the complex process is not readily comprehensible to the untrained eye, there are few concrete outcome measures against which to judge, and evaluation or criticism is left largely to the NGOs. The second question is around the sources of Jack Mongoven's intelligence. The loyalties of the participants in the FCTC process, however peripheral or central, whether non-government, government, "independent" or press, must be made transparent.

Both advocates and industry would do well to treat Mongoven, Biscoe $\&$ Duchin with caution. In Mongoven's world, public health, consumer advocacy, and "the kind of fuzzy thinking which brought us the likes of the precautionary principle" ${ }^{2}$ must bow before the might of corporate "science". Rampton and Stauber point out that MBD have created their own form of scaremongering where the industry is an "innocent giant under attack from radicals", ${ }^{2}$ mobilising grand narratives of modernisation, technology and western values against the "threats" of community concern and the developing world. MBD is not the only PR organisation which gathers intelligence on advocates, and of course advocacy campaigns sometimes use the methods evidenced here: strategic thinking about the strengths and weaknesses of an opponent, using contacts to gather information, selecting the best possible mouthpiece for media coverage. The difference is the distinctly unscientific realm of morality and conscience. MBD are clearly pragmatic about reaching their "issue management" objectives and unconcerned about the impact they have on disempowered others. The challenge to tobacco control is to put procedures in place that will ensure MBD and organisations like them do not impact on local and global tobacco control policy and practice. It seems likely that at both INB4 and the 55th WHA they will be working for their corporate masters to isolate the radicals, re-educate the idealists, flatter the opportunists and co-opt the realists. 


\section{AUTHOR'S AFTERWORD}

This paper was released as an online pre-print on Monday 18 March 2002, in time for INB4. The release generated some publicity, which gained the attention of Ronald Duchin of MBD. His initial response was a retort that MBD are a "Public Policy and Issues Management" firm, not a "Public Relations" firm. Another more important correction: since writing I have learned that Jack Mongoven died of lung cancer in 2001.

Now some objections to which I will not concede so readily. Duchin has claimed that the information in the paper is "almost totally untrue", which is clearly insupportable given the extent of the documentary evidence regarding MBD's work for PM and RJ Reynolds. He also insists that MBD has not been associated with tobacco interests "for quite some time". This indignant distancing from the industry is hard to interpret: it may be bluff; it may be true if "some time" means two years; it suggests some discomfort with being publicly tarred with the tobacco brush. Regardless, the big picture is more important, and the big picture is that there are now multinationals that are more powerful than many governments. With their vast wealth, and assistance from government ratified global agreements, giant corporations of many kinds can control their operating environments. This continues to occur in part because of the influence corporations wield via specialist organisations like MBD. Unless citizens have the courage to challenge this dismal state of affairs, profits will continue to win out over health, equity and justice.

Stacy Carter

April 2002

\section{ACKNOWLEDGEMENTS}

Many thanks to Fiona Byrne, information management specialist for the Australasian Tobacco Document Research Team at the University of Sydney, who first brought MBD to my attention; and to Mary Assunta, a member of the Framework Convention Alliance and experienced tobacco control advocate, whose insights were vital to the development of the paper.

Tobacco Industry Document research at the University of Sydney is supported by grants from the National Health $\delta$ Medical Research Council (Australia) 153857 and the National Institutes of Health (USA) I R01 CA87110-01Al.

\section{REFERENCES}

1 Stauber J, Rampton S. Toxic sludge is good for you! Lies, damn lies and the public relations industry. Monroe, Maine: Common Courage Press; 1995.

2 Rampton S, Stauber J. Trust us, we're experts! How industry manipulates science and gambles with your future. New York: Jeremy P. Tarcher/ Putnam; 2001

3 Duchin R, Blumel R. Status report on projects and projected costs through the end of 1994 (940000). 19941027. RJ Reynolds. Access Date: 20020129. Bates No.: 512010971 -0981.URL: http://www.rirtdocs.com/rirtdocs/

ImageDownloader.dms?DOC RANGE $=512010971+-0981$ \&PDF=true.

4 PR Watch Volume 3 No. 2. Letter and Survey from MBD to the Wilderness Society [online]. 1996 [cited Feb 4th 2002]. Available from internet: http://www.prwatch.org/prwissues/1996Q2/bart.html

5 Stauber J, Rampton S. Flack attack. PR Watch Vol 3 Issue 2 [online]. 1996 [cited Jan 29 2002]. Available from internet: http:// www prwatch org/prwissues/1996Q2/

6 No author. Lulac Business Council Members. 19850500. Tobacco Institute Website. Access Date: 02022002. Bates No.: TITX0032392/2394.URL: http://www.tobaccoinstitute.com/PDF/ TITX0032392 2394.PDF

7 Corporate Affairs corporate cost review. Philip Morris Companies Inc. 19930700. Access Date: 20020129. Bates No. 2046996735/6770.URL: http://www.pmdocs.com/PDF/ 2046996735_6770.PDF

8 William J Kloepfer Jr. Remarks to Board of Directors TI winter meeting 1986. RJ Reynolds. 19860000. Access Date: 29012002. Bates No.: 504988247 -8256.URL: http://www.rirtdocs.com/rirtdocs/ ImageDownloader.dms?DOC_RANGE =504988247+-8256\&PDF=true.

9 Duchin R. SIDS linked to particulate air pollution: forwarding an article and includes information on the authors. 19970804. Philip Morris. Access Date: 20020129. Bates No.: 2065285680.URL: http://www.pmdocs.com/PDF/2065285680.PDF.
10 Multinational Business Services Inc. Invoice Number MPOR-00794. Philip Morris. 19940700. Access Date: 20010129 . Bates No.: 2029377048/7050.URL: http://www.pmdocs.com/PDF/ 2029377048_7050.PDF

11 Annex E. Environment policy. 19940401. Philip Morris. Access Date: 20020129. Bates No.: 2048542212/2217.URL: http:// www.pmdocs.com/PDF/2048542212_2217.PDF.

12 Philip Morris technical synergy symposium on the environment preliminary program draft agenda. 19930200. Philip Morris. Access Date: 20020129. Bates No.: 2046597255/7256.URL: http://www.pmdocs.com/PDF/2046597255 7256.PDF.

13 Grant K. An analysis of key U.S. organizations involved in environmental issues. Philip Morris. 19910104. Access Date: 20010129. Bates No.: 2047375315.URL: URL: http:// www.pmdocs.com/PDF/2047375315.PDF

14 Campanella C. The Working Group: minutes of meeting. 19910123 RJ Reynolds. Access Date: 20020129. Bates No.: 507637790 7791.URL: URL: http://www.rirtdocs.com/rirtdocs/ ImageDownloader.dms?DOC_RANGE $=507637790+-7791$ \&PDF=true

15 Biotech issue team meeting Wednesday, 980617 9:00 am - 11:00 am agenda. 19980617. Philip Morris. Access Date: 20020129. Bates No.: 2065355813.URL: http://www.pmdocs.com/PDF/ 2065355813.PDF

16 Goodheart J. Final: Follow Up Items / GMO Issue Team. 19980619 Philip Morris. Access Date: 20020129. Bates No.: 2065355812.URL: http://www.pmdocs.com/PDF/2065355812.PDF.

17 Biotech issue team meeting Friday, 980626 10:00-12 noon NY time. 19980626. Philip Morris. Access Date: 20020129. Bates No. 2065355810.URL: http://www.pmdocs.com/PDF/2065355810.PDF.

18 Mongoven J. Activists demand famine relief be GMO free. 19980224 Philip Morris. Access Date: 20020129 . Bates No.: $2065356010 /$ 6011 .URL: http://www.pmdocs.com/PDF/2065356010_6011.PDF.

19 Modern biotechnology strategy / issue outline Philip Morris Management Corp. 19970409. Philip Morris. Access Date: 20020129. Bates No.: 2060571679/1697.URL: http:// www.pmdocs.com/PDF/2060571679 1697.PDF.

20 Mongoven J. Indoor Air Quality. 1991 1209. Philip Morris. Access Date: 20020129 . Bates No.: 2024719340.URL: http:// www.pmdocs.com/PDF/2024719340.PDF.

21 Mongoven J. Issue analysis: indoor air pollution status as of 911 1209 1991 1209. Philip Morris. Access Date: 20020129. Bates No. 2024719341/9375.URL: http://www.pmdocs.com/PDF/ 20247193419375.PDF.

22 Mongoven J. Multiple chemical sensitivity as an emerging issue. 19931 100. Philip Morris. Access Date: 20020129. Bates No. 2024138892/8959.URL: http://www.pmdocs.com/PDF/ 2024138892 8959.PDF

23 Mongoven J. Indoor air pollution - who will regulate. 19920217. Philip Morris. Access Date: 20020129. Bates No.: 2022874295/4297.URL: http://www.pmdocs.com/PDF/2022874295_4297.PDF

24 Mongoven J. Indoor air. 19920221. Philip Morris. Access Date: 20020129. Bates No.: 2022874294.URL: http://www.pmdocs.com/ PDF/2022874294.PDF.

25 Mongoven J. SNRT annual meeting. 19980610. Philip Morris. Access Date: 20020129 . Bates No.: 2063123724/3727.URL: http://www.pmdocs.com/PDF/2063123724_3727.PDF.

26 Mongoven J. Liason status at ISO. 19990609. Philip Morris. Access Date: 20020129 . Bates No.: 2065285821.URL: http:// www. pmdocs.com/PDF/2065285821.PDF.

27 Bialous S, Yach D. Whose standard is it, anyway? How the tobacco industry determines the International Organisation for Standardization (ISO) standards for tobacco and tobacco products. Tobacco Control 2001; 10:96-104.

28 Duchin R. Coalition pushes FDA on Tobacco. 19951107. R Reynolds. Access Date: 20020129. Bates No.: 515246495 -6498.URL http://www.rirtdocs.com/rirtdocs/ ImageDownloader.dms?DOC_RANGE=515246495+-6498\&PDF=true.

29 Mongoven J. INFACT's new campaigns against Philip Morris. 19980317. Philip Morris. Access Date: 20020129. Bates No.: 2062197161/7163.URL: http://www.pmdocs.com/PDF/ 2062197161 7163.PDF.

30 Hyde T. FDA activities update. 19950814. Philip Morris. Access Date 20020129. Bates No.: 513968767 -8775.URL: http:// www.rirtdocs.com/rirtdocs/ ImageDownloader.dms? POC RANGE =513968767+-8775\&PDF=true.

31 Mongoven J. Wolfe, Ballin and Douglas. 19920218. Philip Morris. Access Date: 20020129 . Bates No.: 2026168806/8807.URL: http://www.pmdocs.com/PDF/2026168806_8807.PDF

32 Mongoven J. Brundtland wins Director General nomination at WHO 19980127. Philip Morris. Access Date: 20020129. Bates No. 2065285196. URL: http://www.pmdocs.com/PDF/2065285196.PDF.

33 Mongoven J. Brundtland and Whales. 19980724. Philip Morris. Access Date: 20020129 . Bates No.: 2065284694.URL: http:// www.pmdocs.com/PDF/2065284694.PDF

34 WHO Planning - folder from Matthew Winokur's office. 1998 Philip Morris. Access Date: 20020129. Bates No.: Master ID 2065284694/4704.URL: http://www.pmdocs.com/cgi-bin/ rsasearch.asp.

35 Committee of Experts on Tobacco Industry Documents. Tobacco company strategies to undermine tobacco control activities at the World Health Organization. Geneva: World Health Organisation, July 2000.

36 Mongoven J. Memo to Matt Winokur enclosing analysis of the FCTC process. 19970808. Philip Morris. Access Date: 20020129 . Bates No: 2065285679.URL: http://www.pmdocs.com/PDF/2065285679.PDF. 
37 Mongoven J. MDB analysis of WHO convention (FCTC) process. 19971 100. Philip Morris. Access Date: 20020129. Bates No. 2074292078/2082.URL: http://www.pmdocs.com/PDF/ 2074292078_2082.PDF

38 Winokur M. Memo distributing Executive Summary of MBD's report on the WHO tobacco control convention. 19971201. Philip Morris. Access Date: 20020129. Bates No.: 2074292077.URL: URL: http://www.pmdocs.com/PDF/2074292077.PDF

39 Mongoven J. Memo forwarding MBD's analysis of NGOs in relation to UN processes. 19971210. Philip Morris. Access Date: 20020129. Bates No.: 2065284804.URL: http://www.pmdocs.com/PDF/ 2065284804.PDF

40 Mongoven J. Memo:World Health Organisation. 19981009. Philip Morris. Access Date: 20020129. Bates No.: 2065284638.URL: http://www.pmdocs.com/PDF/2065284638.PDF.

41 Winokur $\mathrm{M}$. Memo forwarding background brief on the $\mathrm{WHO}$. 19981012 . Philip Morris. Access Date: 20020129. Bates No. 2065284665.URL: http://www.pmdocs.com/PDF/2065284665.PDF.

42 Mongoven J. Memo forwarding IFC issues paper. 19981208. Philip Morris. Access Date: 20020129. Bates No.: 2065284576.URL: http://www.pmdocs.com/PDF/2065284576.PDF.

43 Presumably (but not certainly) Raúl Uranga, who was staff at the United Nations System Focal Point on Tobacco or Health, a unit which preceded the TFI and was sited in the UN Economic and Social Council (ECOSOC), a policy decision seen as a victory by the industry at the time. This document suggests that the industry did have strong links to the focal point

44 Kush A. Email re: International Policy Conference on Children and Tobacco. 19990625. Philip Morris. Access Date: 20020129. Bates No.: 2065560545.URL: http://www.pmdocs.com/PDF/ 2065560545.PDF.
45 Winokur M. Email to Anne Kush re: International Policy Conference on Children and Tobacco. 19990628. Philip Morris. Access Date: 20020129. Bates No.: 2065560544.URL: http://www.pmdocs.com/ PDF/2065560544.PDF

46 Personal communication to the author from Mary Assunta, participant.

47 Mongoven J. International policy conference on children. 19990303 Philip Morris. Access Date: 20020129 . Bates No.: 2070740803/ 0809.URL: http://www.pmdocs.com/PDF/2070740803 0809.PDF.

48 Mongoven J. Memo to Matthew Winokur. 19990422. Philip Morris. Access Date: 20020129. Bates No.: 2065285547.URL: http://www.pmdocs.com/PDF/2065285547.PDF

49 Mongoven J. Intelligence report on the activities of the Tobacco Free Initiative. 19990422. Philip Morris. Access Date: 20020129. Bates No. 2065285570/5571.URL: http://www.pmdocs.com/PDF/ 2065285570 5571.PDF.

50 Winokur M. Draft cover for followup to regions. 19990609. Philip Morris. Access Date: 20020129. Bates No.: 2065560461.URL: http://www.pmdocs.com/PDF/2065560461.PDF

51 Winokur M. Revised country comments at WHA compiled by MBD. 19990618. Philip Morris. Access Date: 20010129. Bates No. 2065560644.URL: http://www.pmdocs.com/PDF/2065560644.PDF

52 US Centers for Disease Control and Prevention. List of participants in public hearings on FCTC [online]. 2001 [cited Jan 28 2002]. Available from internet: http://www.cdc.gov/tobacco/global/fctc/ fctc participants. htm

53 ABC News/World News. Bush administration relaxing US role in worldwide tobacco reform [online]. August 4, 2001 [cited Feb 06 2002]. Available from internet: http://www.fctc.org/news 179.shtml

54 Personal communication to the author from Mary Assunta, participant in FCTC process as NGO representative. 